\title{
Meteorologically-induced mesoscale variability of the North-western Alboran Sea (southern Spain) and related biological patterns
}

\author{
D. Macías $^{\text {a,* }}$, M. Bruno ${ }^{\text {b }}$, F. Echevarría ${ }^{\text {c }}$, A. Vázquez ${ }^{\text {b }}$, C.M. García ${ }^{\text {a }}$ \\ ${ }^{a}$ Departamento de Biología, Área de Ecología. Facultad de Ciencias del Mar y Ambientales, Universidad de Cádiz, Avda. Republica Saharaui s/n, \\ 11510 Puerto Real, Cádiz, Spain \\ b Departamento de Física Aplicada, Facultad de Ciencias del Mar y Ambientales, Universidad de Cádiz, 11510 Puerto Real, Cádiz, Spain \\ ${ }^{\mathrm{c}}$ Centro Andaluz de Ciencias y Tecnología Marinas (CACYTMAR), Avda. Republica Saharaui s/n, 11510 Puerto Real, Cádiz, Spain
}

Received 26 July 2007; accepted 13 December 2007

Available online 3 January 2008

\begin{abstract}
Hydrographic mesoscale structures in the North-western Alboran Sea show a high variability induced by a number of different factors. One of the most important is the differences in atmospheric pressure over the Mediterranean basin when compared to the Gulf of Cádiz. This difference modulates the zonal wind field in the Alboran Sea and the intensity of the Atlantic inflow through the Strait of Gibraltar, also affecting the formation and extension of the Western Alboran Gyre (WAG). When westerly winds are dominant, lower atmospheric pressure in the Mediterranean enhances the inflow of Atlantic waters causing the Atlantic Jet to be located in the vicinity of the Spanish shore, creating a well-defined frontal zone in front of Estepona Cove. In this situation, the coastal upwelling is enhanced, leading to a minimum in sea surface temperature and a maximum of surface nutrient concentrations located in the coastal area. The vertical position of the chlorophyll maximum found in these circumstances appeared to be controlled by the nutrient availability. On the other hand, when easterly winds prevail, higher atmospheric pressure in the Mediterranean leads to a reduced inflow and the oceanographic and biological structures are clearly different. The Atlantic Jet moves southward flowing in a south-eastern direction, changing the structure of the currents, resulting in an enhanced cyclonic circulation extending throughout the North-western Alboran Sea basin. These physical alterations also induce changes in the distribution of biogeochemical variables. Maximum nutrient and chlorophyll concentrations are located further off the coast in the central area of the newly created cyclonic gyre. During these easterlies periods coastal upwelling stops and the distribution of phytoplankton cells seems to be mainly controlled by physical processes such as advection of coastal waters to the open sea.
\end{abstract}

(C) 2007 Elsevier Ltd. All rights reserved.

Keywords: Spain; Alboran Sea; Atlantic jet; atmospheric pressure; wind-driven circulation; upwelling; water masses; chlorophyll distribution

\section{Introduction}

The North-western (NW) Alboran Sea is a highly dynamic system which exhibits large variations in bio-physiochemical parameters at a range of spatial and temporal scales due to the presence of a number of hydrographic structures, such as fronts, cyclonic and anticyclonic gyres and coastal upwelling

\footnotetext{
* Corresponding author.

E-mail addresses: diego.macias@uca.es (D. Macías), miguel.bruno@ uca.es (M. Bruno), fidel.echevarria@uca.es (F. Echevarría), agueda.vazquez@ uca.es (A. Vázquez), carlos.garcia@uca.es (C.M. García).
}

(Minas et al., 1987; Tintoré et al., 1991; Gleizon et al., 1996; Viúdez et al., 1996; Gomís et al., 1997; Rodríguez et al., 1998). Within this region, at least three different water masses can be found; SAW (Surface Atlantic Water), NACW (North Atlantic Central Water) and a mixture of different Mediterranean waters (Levantine Intermediate Water (LIW) and Western Mediterranean Deep Waters (WMDW)), which we will call Mediterranean Waters (MW) for the purposes of this investigation.

The main forcing agent modulating the hydrological processes in this zone, and in the whole Alboran Sea basin, is the Atlantic jet, which enters through the Strait of Gibraltar 
(Bormans and Garret, 1989; Benzohra and Millot, 1995; García-Lafuente et al., 1998). This jet is mainly composed of a mixture of MW and Atlantic waters; with the proportions of each being related to the tidal cycles (see Macías, 2006; Macías et al., 2006 and references therein). The jet is usually situated in the upper water layer with a typical width of about $30 \mathrm{~km}$ (Perkins and Saunders, 1984), and an eastward advection velocity of around $1 \mathrm{~m} \mathrm{~s}^{-1}$ (Perkins et al., 1990; GarcíaLafuente et al., 1999). This flowing jet contributes to the maintenance of the two main anticyclonic gyres that characterise the circulation within the Alboran Sea, the Western Alboran Gyre (WAG) and the more elusive Eastern Alboran Gyre (EAG) (e.g. Lacombe, 1971; Lanoix, 1974; Arnone et al., 1990; La Violette, 1984).

The variability of the flow through the Strait of Gibraltar in the subinertial frequencies (characterised by periods from a few days to several months) has been basically explained by the atmospheric pressure variations over the western Mediterranean (Crepon, 1965; Candela et al., 1989; García-Lafuente et al., 2002). This phenomenon also significantly affects the extent of the Atlantic jet entering the Alboran Sea and therefore, the western gyre dynamics. Candela et al. (1989) and García-Lafuente et al. (2002) both found that subinertial barotropic flows kept an almost counter-phase $\left(180^{\circ}\right)$ with respect to the atmospheric pressure fluctuations for oscillating periods between 3 and 80 days. Thus, within this period range, an increase (or decrease) in the atmospheric pressure is followed by a subsequent decrease (or increase) in intensity of the Atlantic inflow.

García-Lafuente et al. (1998) investigated the relation between subinertial flows forced by atmospheric pressure variations over the western Mediterranean and the western gyre state. They found that subinertial barotropic velocities inferred from cross-strait sea level differences (between Ceuta and Algeciras), had a significant correlation with the differences in atmospheric pressure between the western Mediterranean and the Gulf of Cadiz. There was, however, a period when both series were uncorrelated. The analysis of this exceptional period led the authors to postulate that changes in the gyre size were linked to the alternation of the Atlantic inflow in the eastern most side of the Strait between periods of subcritical and supercritical states. A well-developed gyre was observed under subcritical conditions, whiles under supercritical conditions the Atlantic Jet, which entered the Alboran Sea with a much stronger velocity, was displaced southward, causing the gyre to be squashed across its north-south axis. In contrast Sarhan et al. (2000) found that the size of the gyre was correlated with the velocity intensity of the Atlantic jet in an inverse manner, that is, a bigger gyre was related to a stronger velocity and vice versa. Finally, Vargas-Yañez et al. (2002), using SST images combined with current velocity observations in the eastern section of the Strait, reported gyre collapse episodes that seemed to be linked to the diminution of the inflow intensity caused by atmospheric pressure increases over the western Mediterranean.

Wind forcing is a direct consequence of atmospheric pressure differences, which could also modulate the position and intensity of the Atlantic jet, thereby controlling the distribution of the water masses within the NW Alboran Sea (e.g. Crepon, 1965; Cheney and Doblar, 1982; Sarhan et al., 2000; Vargas-Yáñez et al., 2002; Macías et al., 2007). Additionally, a bimodal annual pattern of the jet, where the jet frequently flows in the vicinity of the Spanish coast in summer and closer to the Moroccan coast in winter, has been described by a number of authors (Bormans and Garret, 1989; Vargas-Yañez et al., 2002).

Biogeochemical signatures within the area are tightly coupled to physical forcing. Typically nutrient and phytoplankton distributions are highly concentrated in the north, near the Spanish shore, a zone usually known as the Estepona upwelling (García-Lafuente and Cano, 1994). An oligotrophic region associated with the anticyclonic gyre is also observed further south (Minas et al., 1987; Packard et al., 1988). However, the variability of the hydrodynamic conditions has a strong influence on the spatial distribution and on the size structure of the pelagic community in the area (Rubín et al., 1992; Rodríguez et al., 1998; Prieto et al., 1999).

Over longer temporal scales, annual cycles of surface chlorophyll concentration have been described for this area using satellite imagery analysis (e.g. García-Gorriz and Carr, 1999; Baldacci et al., 2001; Macías et al., 2007). Maximum surface chlorophyll concentrations are usually found at the end of winter or beginning of spring (February and March) and the minimum values are observed in mid summer (July and August). Interannual variations associated with climatologic tendencies within the North Atlantic basin have also been reported (Macías, 2006).

Thus, the aim of the present work was to study the variability of hydrodynamic structures and biological patterns induced by wind and atmospheric pressure in the NW Alborán Sea. A set of sampling grids were designed to study spatial variability in physical, chemical and biological parameters during different periods of the year. These periods coincided with specific meteorological forcing conditions. Results for each survey are discussed within the framework of the dominant forcing factors and some general conclusions about the induced biological patterns are assessed.

\section{Methods}

Three different cruises were made between 2002 and 2003 in the NW Alboran Sea on board B.C. Malaspina, B.C. Tofiño and B.I.O. Hespérides. During each cruise a grid composed of 17 to 51 stations covering the NW Alboran Sea sector adjacent to the Strait of Gibraltar (Fig. 1) was sampled. Due to the typical spatial distribution of the different water masses in the area of study, with the Atlantic jet entering from the Strait in a NE direction, the sampling grids were designed to cover the eastern side of the Strait of Gibraltar and the adjacent area of the Alboran Sea, including the NW coastal area where the Estepona upwelling is located. The grids were specifically designed with a high spatial resolution across the frontal area in order to adequately solve the strong gradients typical of such zones.

In each station, a CTD cast was completed to obtain information of the physical structure of the water column. The information obtained from this CTD cast was used to estimate 


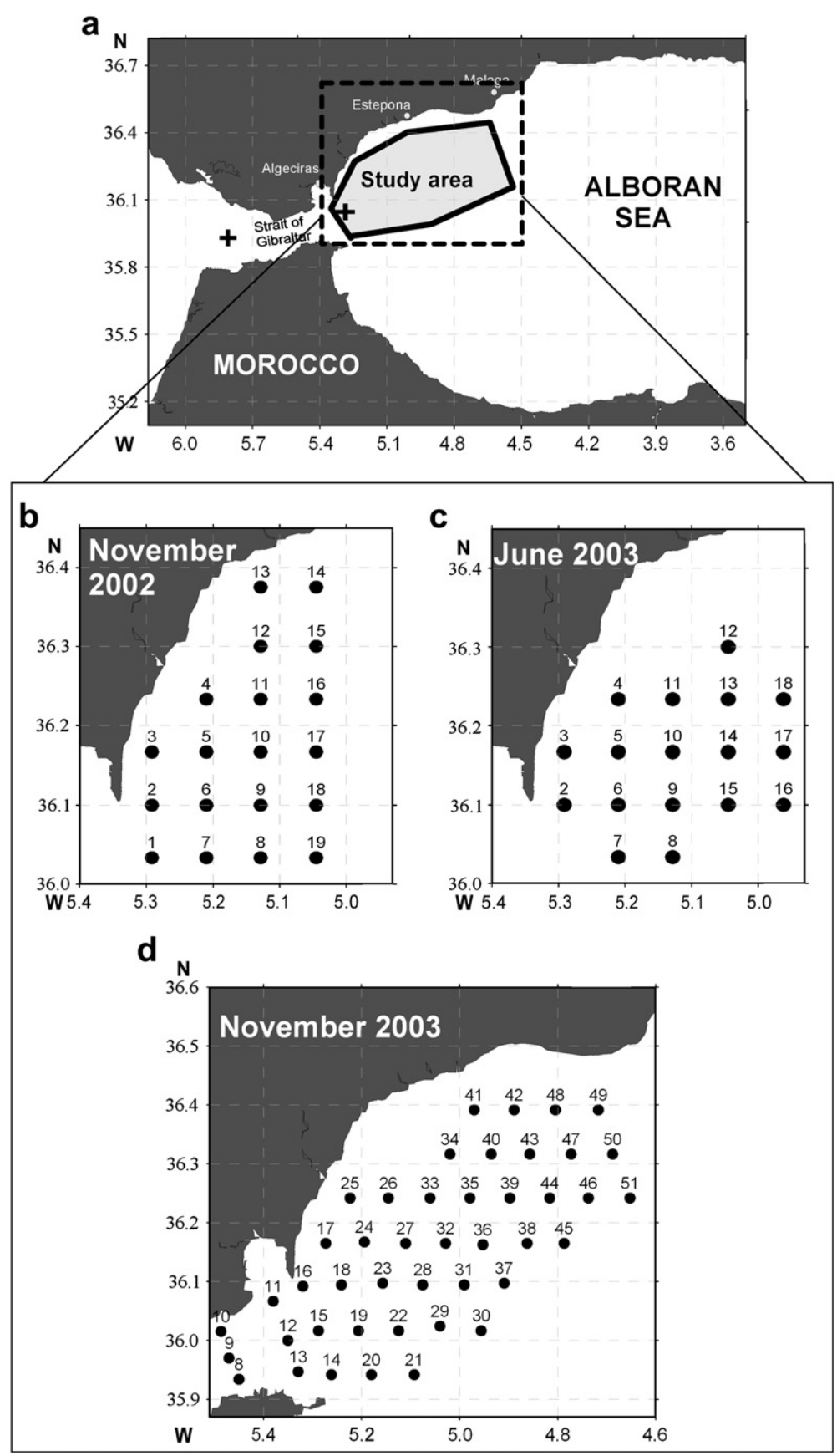

Fig. 1. (a) Map showing the location of the study area. (b) Grid sampled during cruise N-G. (c) Grid sampled during cruise J-G. (d) Grid sampled during cruise H-G. Crosses mark the positions of the two moorings used for flow analysis.

the percentage of NACW present in the water column after Bray et al. (1995) and Macías (2006). With this procedure, all the TS information of the CTD cast is reduced to an average single point in the diagram and using three-equation threeincognitos system, the proportion of each water mass (SAW, NACW and MW) is calculated.

Water samples were collected at different depths $(5,20,30$, 50,75 and $150 \mathrm{~m}$ ) at each station using Niskin bottles mounted on a sampling rosette to acquire information on basic biological and biogeochemical variables (chlorophyll and inorganic nutrient concentrations and picoplankton assemblage composition). Additionally, during surveys H-G1 and H-G2 (see Table 1) current velocity profiles were acquired at each CTD station by a vessel-mounted ADCP. ADCP profiles spanned the water column from 12.5 to $700 \mathrm{~m}$ depth with a vertical resolution of $8 \mathrm{~m}$.

Total chlorophyll concentration was estimated by filtering $0.5 \mathrm{~L}$ of seawater through Whatman GF/F filters and using the fluorometric method described by Yentsch and Menzel (1963) and modified by Holm-Hassen et al. (1965). The percentage of chlorophyll contained within cells larger than $10 \mu \mathrm{m}$ was measured by filtering $5 \mathrm{~L}$ of seawater through a nylon mesh 
Table 1

Dates, vessels, mean zonal wind and period of wind averaging for the different cruises carried out

\begin{tabular}{|c|c|c|c|c|c|}
\hline Cruise & Code & Dates & Vessel & $\begin{array}{l}\text { Mean zonal } \\
\text { wind }\left(\mathrm{km} \mathrm{h}^{-1}\right)\end{array}$ & Period of wind averaging \\
\hline November 2002 & $\mathrm{~N}-\mathrm{G} 1$ & $7-8 / 11 / 2002$ & B.C. Malaspina & -4 & $6-8 / 11 / 2002$ \\
\hline November 2002 & $\mathrm{~N}-\mathrm{G} 2$ & $12-13 / 11 / 2002$ & B.C. Malaspina & 15 & $8-13 / 11 / 2002$ \\
\hline June 2003 & J-G1 & $4-5 / 06 / 2003$ & B.C. Tofiño & 8 & $1-5 / 06 / 2003$ \\
\hline June 2003 & $\mathrm{~J}-\mathrm{G} 2$ & $11-12 / 06 / 2003$ & B.C. Tofiño & -30 & $8-12 / 06 / 2003$ \\
\hline Hespérides 2003 & $\mathrm{H}-\mathrm{G} 1$ & $7-11 / 11 / 2003$ & B.I.O. Hespérides & 4 & $4-11 / 11 / 2003$ \\
\hline Hespérides 2003 & $\mathrm{H}-\mathrm{G} 2$ & $15-19 / 11 / 2003$ & B.I.O. Hespérides & -12 & $13-19 / 11 / 2003$ \\
\hline
\end{tabular}

of $10 \mu \mathrm{m}$ of nominal pore diameter. The retained material was then collected by washing the mesh using a sprayer filled with clean, filtered $(0.7 \mu \mathrm{m})$ seawater, and filtered through Whatman GF/F filters following the same protocol described above. The chlorophyll contained within cells larger than $10 \mu \mathrm{m}$ was compared to the total chlorophyll concentration of a sample to obtain a percentage of chlorophyll attributed to larger cells.

To determine inorganic nutrient concentration three $12 \mathrm{ml}$ replicates of filtered seawater (Whatman GF/F filters) were collected and analysed for each station and depth. Concentrations of nitrate, nitrite, phosphate, silicate and ammonia were measured using an autoanalyser Technicon-TRAACS 800 following the techniques of Strickland and Parsons (1972). Inorganic nutrient concentrations were also used to calculate the depth of the nutricline ( $\mathrm{Znn}$ ); defined as the minimum depth in which nitrate + nitrite concentration is $>1 \mu \mathrm{M}$ (Eppley et al., 1969; Wash, 1988).

In the last cruise, carried out in November 2003, picoplankton composition was analysed using a flow cytometer FACSCalibur (Becton Dickinson). Acquisition time was set to $600 \mathrm{~s}$ and MilliQ water was used as sheath fluid. Acquisition and data analysis were accomplished with the software CELL Quest ${ }^{\mathrm{TM}}$ (Becton Dickinson).

During each cruise the sampling grid was repeated on two occasions under different meteorological conditions (Table 1). Winds were measured in the Algeciras station of the "Instituto Nacional de Meteorología" (Spanish Institute of Meteorology). Westerlies have been represented as positive values and easterlies as negative values of the mean zonal component. To calculate the mean zonal wind, a period comprising from at least 2 days before the sampling to the end of the sampling has been considered (see detailed period in Table 1). Thereby this average value should be considered as a representation of the mean meteorological forcing during a significant period of time exceeding that of the measurements.

As can be seen in Table 1, three surveys were carried out with westerly winds blowing (N-G2, J-G1 and H-G1) and another three were made while easterlies prevailed (N-G1, $\mathrm{J}-\mathrm{G} 2$ and H-G2). Results were arranged into these two sets, with westerlies- and easterlies-influenced situations being analysed separately.

All the data series used for Pearson's correlation analysis (see next section) were tested for normality using the Kolmogorov-Smirnov test $(n>100)$. As a result of these analyses, we concluded that all of the data series were normally distributed $(p<0.05)$.
To examine the correlation between gyre dynamics and meteorologically forced subinertial flows we used three sources of data. First of all, historical atmospheric pressure and wind data were taken from the ERA Project of the ECMWF (European Centre for Medium-Range Forecasts). We used also current velocity records from two mooring lines, one of the data series comes from the Experiment Strait 94-96 led by Woods Hole Oceanographic Institution and another from a mooring placed on the Camarinal Sill during the November 2003 cruise (positions shown in Fig. 1). Finally we analysed satellite sea surface temperature (SST) images for selected dates.

The atmospheric pressure from ECMWF used in the analysis was obtained by averaging data from nine stations in the Western Mediterranean and four stations in the Gulf of Cadiz, whereas wind data was calculated as the average of four stations nearest to the Alborán Sea (Fig. 2a).

Additionally, atmospheric pressure data were obtained for the period of the sampling from meteorological buoys placed in the western (Alboran buoy) and eastern (Cabo de Gata buoy) Alboran basin by the "Puerto del Estado" (Entity of Spanish Harbours).

\section{Results}

\subsection{Effects of meteorological forcing on western gyre variations}

\subsubsection{Analysis of historical data sets}

Analysing the meteorological time series (Fig. 2) it can be seen that pressure variations relative to the atmospheric pressure over the Gulf of Cadiz basin are highly correlated with wind variations in the Alboran Sea region $\left(r^{2}=0.72\right.$; $p<0.001)$. As is shown in Fig. $2 \mathrm{c}$ and $\mathrm{d}$, this correlation is so tight that any decrease or increase in the atmospheric pressure over the western Mediterranean leads to a westerly or easterly wind respectively. Therefore, it seems clear that the predominant wind forcing is very much influenced by the atmospheric pressure over the western Mediterranean. Easterly episodes are associated with conditions of high atmospheric pressure over the Mediterranean and a consequent diminution in the intensity of the inflow entering the Alboran Sea. Reciprocally, westerly episodes coincide with a low atmospheric pressure over the Mediterranean, which leads to an increase in the inflow intensity. In this sense, since atmospheric pressure variations drive both, wind and water flows, easterly 

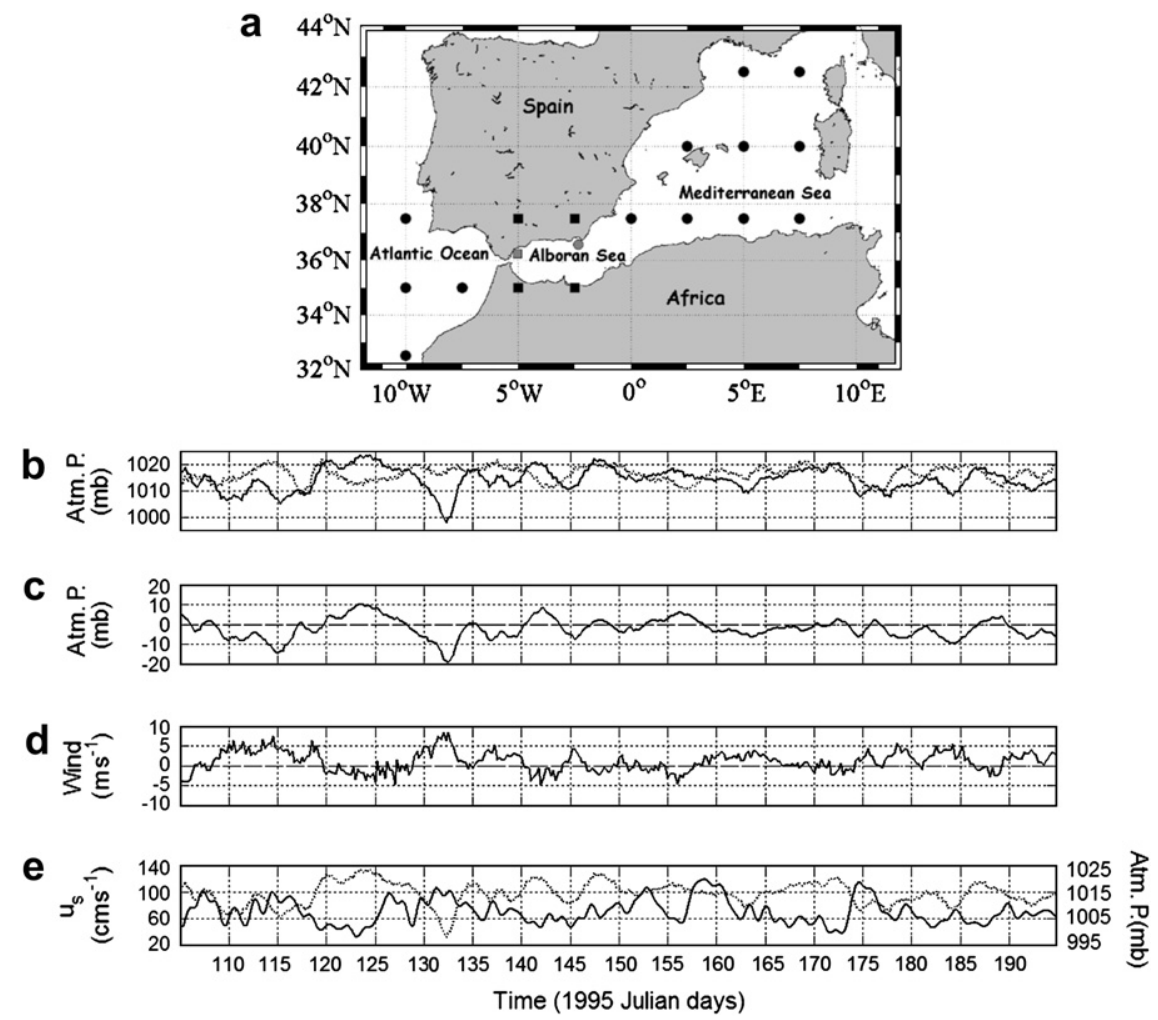

Fig. 2. (a) Map showing location of the meteorological data stations. Circles show the stations where atmospheric pressure was measured and squares show the stations for wind. Black colour shows data from ECMFW and grey colour shows data from Alboran and Cabo de Gata buoys. (b) Time series of mean atmospheric pressure in the Mediterranean Sea (continuous line) and Atlantic Ocean (dotted line). (c) Time series of difference in atmospheric pressure between the Mediterranean Sea and the Atlantic ocean. (d) Time series of mean wind (zonal component) in the Alboran Sea area. (e) Time series of the subinertial flow (u component) at the eastern Gibraltar Strait mooring (continuous line) and mean atmospheric pressure in the Mediterranean Sea (dotted line).

and westerly conditions may only be mere indicators of the state that the inflow experiences under the effect of atmospheric pressure variations over the western Mediterranean. This idea must be kept in mind when interpreting gyre variations as a response to meteorological forcing.

In fact, the intensity of flow measured by a current meter placed at $50 \mathrm{~m}$ depth (Fig. 2e) located in the easternmost section of the Strait (Fig. 1), is well correlated with the atmospheric pressure variations over the western Mediterranean during the whole record in agreement with previous works (Crepón, 1965; Candela et al., 1989).

In Fig. 3 two SST images corresponding to 1995 Julian days 133 and 169 are shown. The first one (Fig. 3a) was acquired in a period when atmospheric pressure over the western Mediterranean had experienced a considerable decrease, while the second one (Fig. 3b) was under high atmospheric pressure conditions. As can be observed, behaviour of inflow velocities around the date of the images are in good agreement with their expected responses to the atmospheric pressure variations (Fig. 2e). During the high atmospheric pressure event, a decrease in the inflow velocity was recorded while the low atmospheric pressure event provoked a drastic reinforcement in the inflow intensity.

Looking at the signature of the western gyre in the images we can see that during the high atmospheric pressure event, with easterly winds prevailing (Fig. 2d), the gyre occupied a lesser extent than during the low pressure event, where the western gyre was well developed occupying almost the whole of the northsouth extent of the Alboran Sea. The different size of the gyre during the two events can be explained in accordance with the observed inflow intensity and volume conservation arguments; when the inflow intensity increases, a greater volume of water feeds the gyre and so, disregarding variations in upper layer thickness, the gyre must growth in the horizontal dimension.

However, the response of the western gyre to atmospheric pressure variations is not always the same (García-Lafuente et al., 1998; Vargas-Yañez et al., 2002). To adequately assess the gyre response to atmospheric forcing through satellite image analysis, a given satellite scene demands the knowledge of the initial state of the gyre in the situation previous to the varying meteorological conditions that promote the changes in the gyre. In this sense, within our observations periods (in both historical and new observations), we have found situations when a new western gyre was in formation after the collapse of a previous one. As suggested by Vargas-Yañez et al. (2002), this collapse seems to be related to events where atmospheric pressure increases provoke a severe diminution of the inflow intensity (which is even able to reverse the upper flow direction toward the Atlantic). Under circumstances like these, the western gyre is no longer fed by the Atlantic Jet and consequently disappears. A representative picture for this situation, occurring during our observation period, is illustrated in Fig. 4 where three satellite images corresponding to 1995 
a

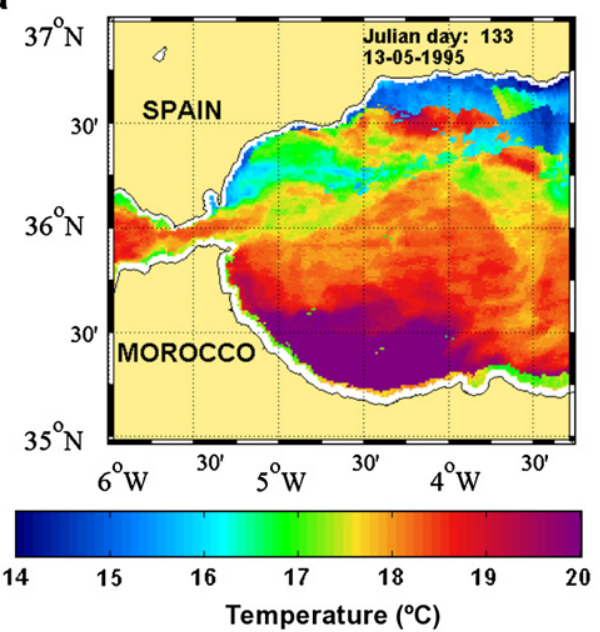

b

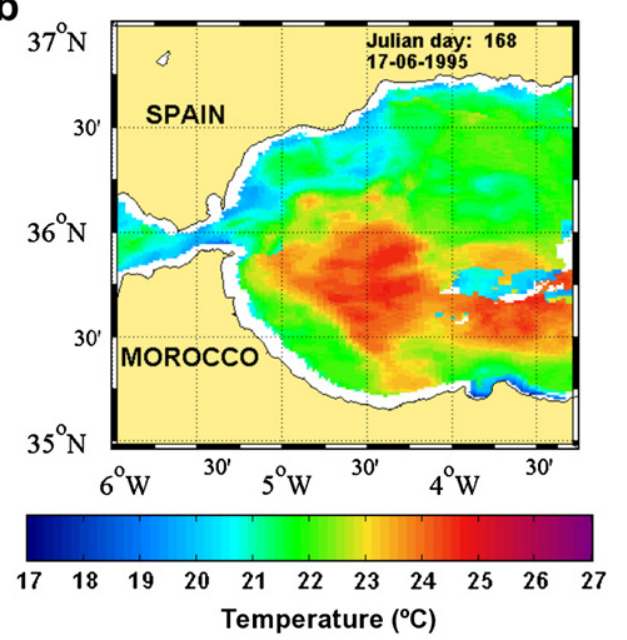

Fig. 3. (a) SST image showing a well developed gyre (13/05/1995), and (b) a poorly developed gyre (17/06/1995).

Julian days 114, 115 and 119 are shown. As can be seen, the images clearly describe the formation of a new western gyre. Analysing the inflow intensities at the time of this event (Fig. 2e), we find that it corresponded with a period of increased inflow which, following Bormans and Garret (1989), favoured the formation of a new gyre instead of a coastal mode following the African coast.

\subsubsection{Analysis of meteorological conditions during cruises}

Atmospheric pressure dynamics throughout the performed cruises were derived from a set of meteorological buoys placed through the Alboran Sea.

During the November 2002 cruise mean zonal winds were easterlies and westerlies for grids N-G1 and N-G2 respectively (Table 1), whilst atmospheric pressure at the Alboran buoy was higher during N-G1 than during N-G2 (Fig. 5). During the June 2003 cruise winds changed from westerlies (during $\mathrm{J}-\mathrm{G} 1$ ) to easterlies (J-G2) (Table 1) and atmospheric pressure was lower for J-G1 than for J-G2 (Fig. 6). The expected response of subinertial flow to atmospheric pressure variations is that the inflow be increased during low-pressure conditions
(N-G2 and J-G1 grids) and reduced when there is high atmospheric pressure over the Alboran basin $(\mathrm{N}-\mathrm{G} 1$ and $\mathrm{J}-\mathrm{G} 2$ grids).

Finally, during the November 2003 cruise mean zonal winds around the time of the surveys were westerlies and easterlies for HG1 and HG2 grids respectively (Table 1). However, wind direction was very variable during the cruise, particularly for the H-G2 mesh (Fig. 7). Looking at the atmospheric pressure data recorded at the Cabo de Gata buoy shown in Fig. 7b, we can see that both H-G1 and H-G2 were presumably performed under low atmospheric pressure conditions over the western Mediterranean. In addition, Fig. 7c shows a time series of subinertial flow velocity taken from the mooring placed in the western side of the Strait of Gibraltar (see Fig. 1) covering the major part of the cruise period. By comparing Fig. 7b and c, low/high velocity intensity is related to high/low atmospheric pressure situation over the western Mediterranean (Fig. 2). With the information given in these figures, taken as a reference for the state of subinertial flow, we find that both grids are examples of a common situation, with an enhanced inflow of Atlantic waters through the Strait of Gibraltar. a

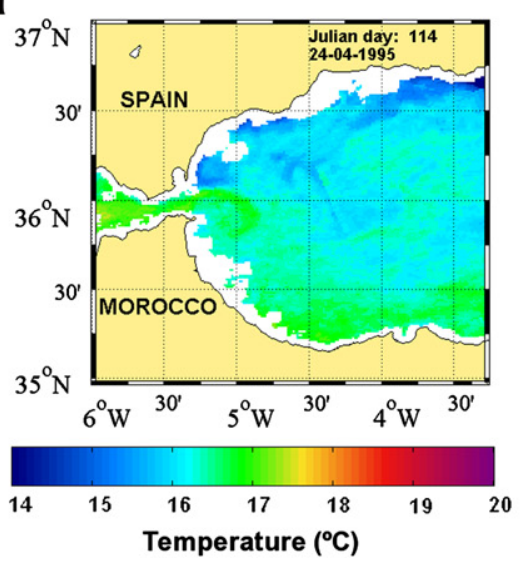

b

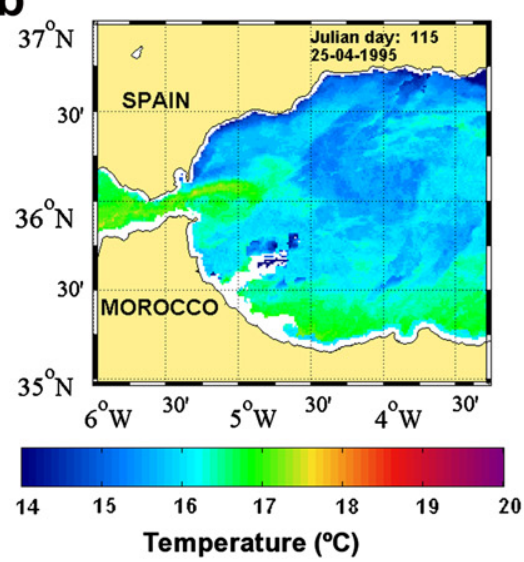

C

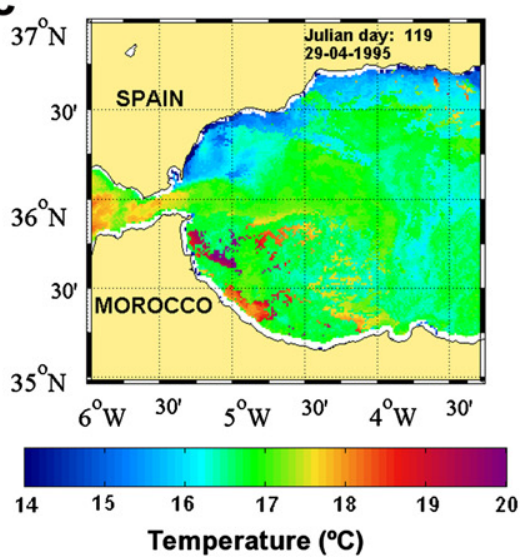

Fig. 4. (a-c) SST images of 24/04/1995, 25/04/1995 and 29/04/1995, respectively. 
a



b

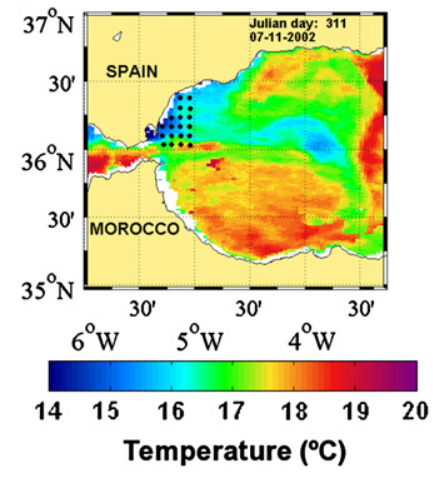

C

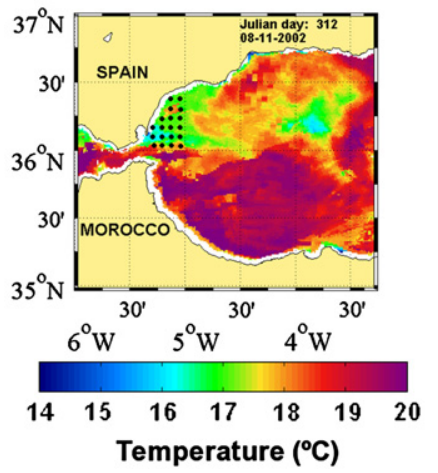

d

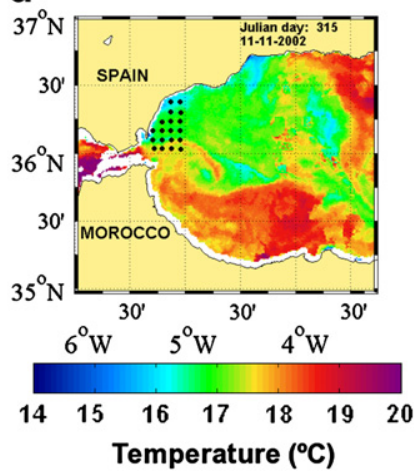

Fig. 5. November 2002 cruise. (a) Time series of atmospheric pressure from Alboran buoy. (b-d) SST image of 07/11/2002, 08/11/2002 (N-G1) and 11/11/2002 (N-G2), respectively. Dots show the stations grid sampled during that cruise.
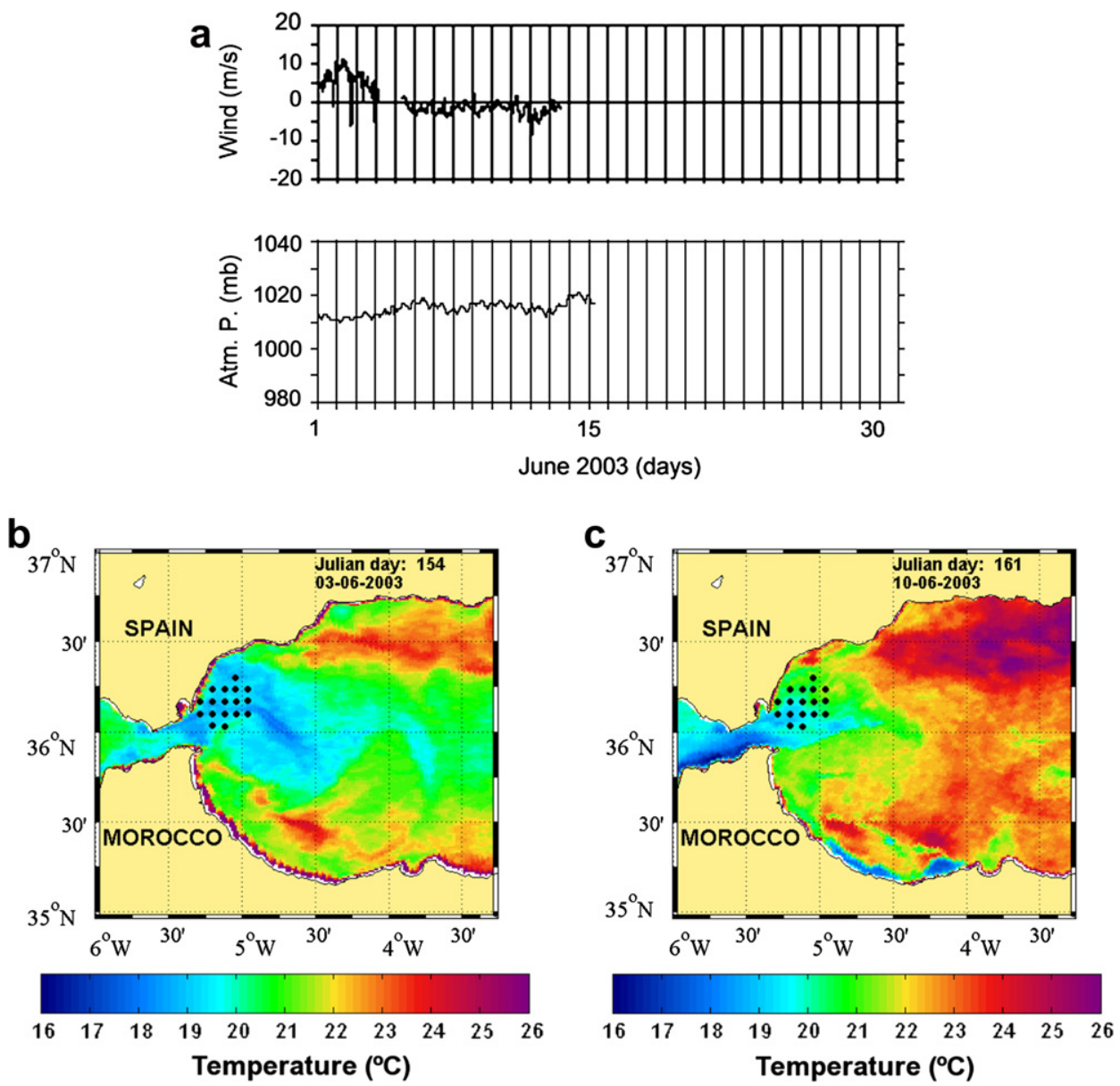

Fig. 6. June 2003 cruise. (a) Time series of wind (zonal component) from Alboran buoy and atmospheric pressure from Cabo de Gata buoy. (b, c) SST images of 03/06/2003 (J-G1) and 10/06/2003 (J-G2), respectively. Dots show the stations grid sampled during that cruise. 
a

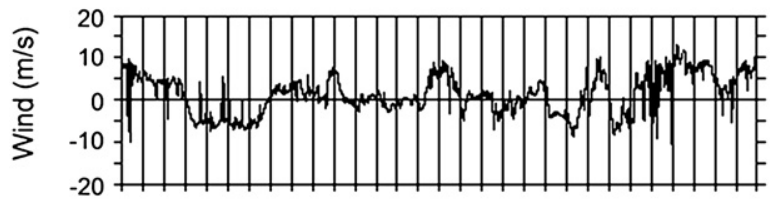

b
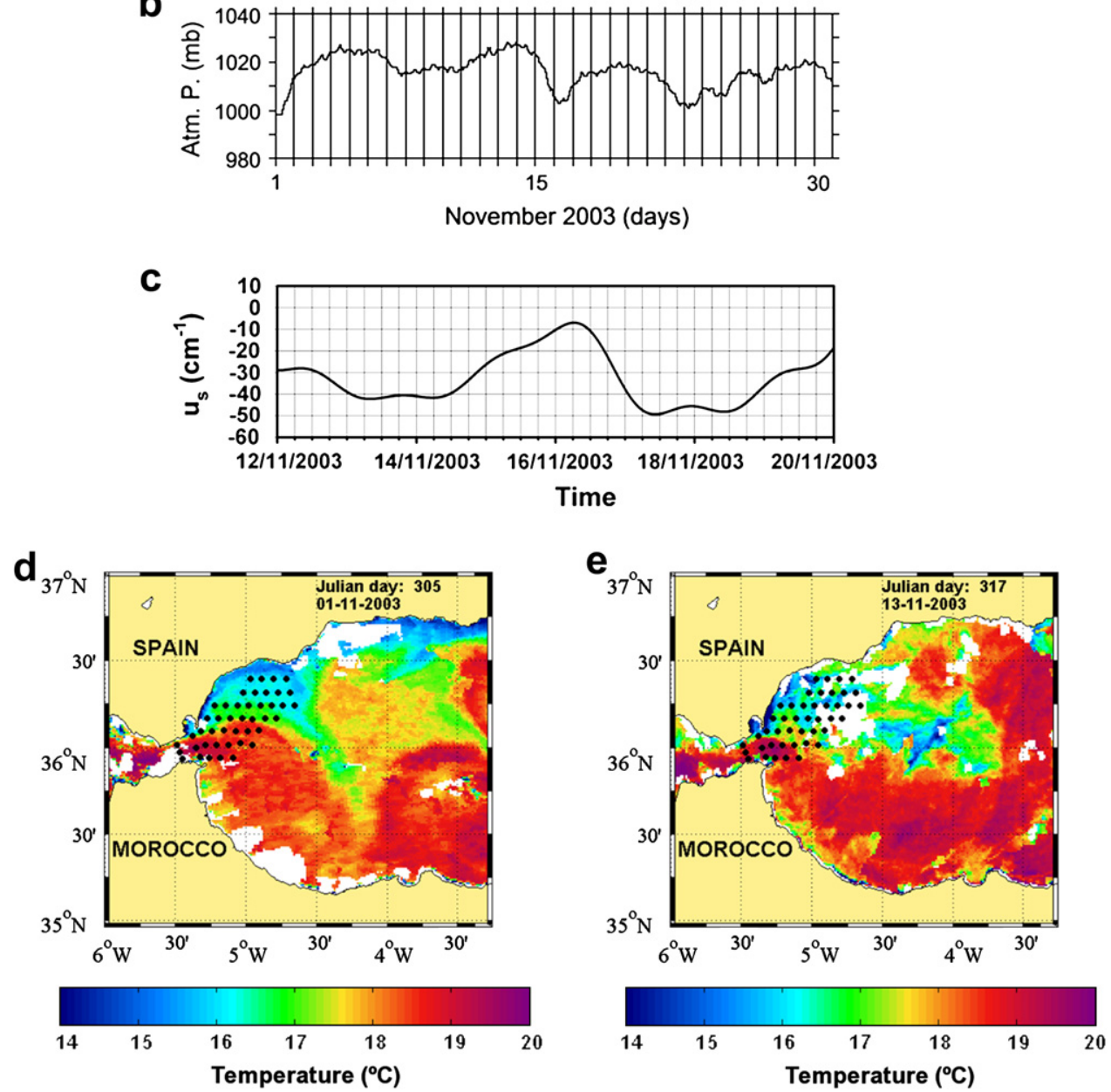

Fig. 7. November 2003 cruise. (a) Time series of wind (zonal component) from Alboran buoy. (b) Atmospheric pressure from Cabo de Gata buoy. (c) Subinertial flow at eastern Gibraltar Strait. (d, e) SST images of 01/11/2003 (H-G1) and 13/11/2003 (H-G2), respectively. Dots show the stations grid sampled during that cruise.

\subsection{Westerly winds}

Three surveys were made when westerlies predominated; N-G2, J-G1 and H-G1 (Table 1). As stated above, this situation corresponds with a lower atmospheric pressure over the western Mediterranean and an enhanced Atlantic inflow. The TS diagrams from each station performed in those samplings are presented in Fig. 8. Each profile has been classified according to the presence ( $>5 \%$, squares in Fig. 8 ) or absence $(<5 \%$, triangles in Fig. 8) of the less-abundant NACW. Spatially, the NACW signal is only detected in the southern half of the sampling grids, indicating the presence of the Atlantic waters in that zone (i.e. the Atlantic jet). Consequently, a frontal zone between Atlantic and coastal waters should be located around the zone marked with the thick black line in Fig. 8.
In Fig. 9 a surface average of different properties are presented $(0-50 \mathrm{~m})$. The Atlantic jet usually occupies the upper $40-60 \mathrm{~m}$ of the water column (Gil, 1994) and a homogeneous Mediterranean water mass extends below, so averaging the upper $50 \mathrm{~m}$ of the water column could maximise differences at the same time that provides a good description of the surface water layer. Mean temperature and salinity in the upper $50 \mathrm{~m}$ of the water column in these surveys (Fig. 9a and b) confirm the existence of an Atlantic water mass (with relatively higher temperature and lower salinity) extending in the surface at the south of the sampled area. Current velocity, again averaged over the upper $50 \mathrm{~m}$, recorded by the VM ADCP during $\mathrm{H}$ G1 (arrows in Fig. 9) clearly showed the presence of the Atlantic jet in the southern half of the sampling grid flowing to the north-east at approximately $1 \mathrm{~m} \mathrm{~s}^{-1}$. Further north, there was a colder and saltier water mass that corresponds with the 

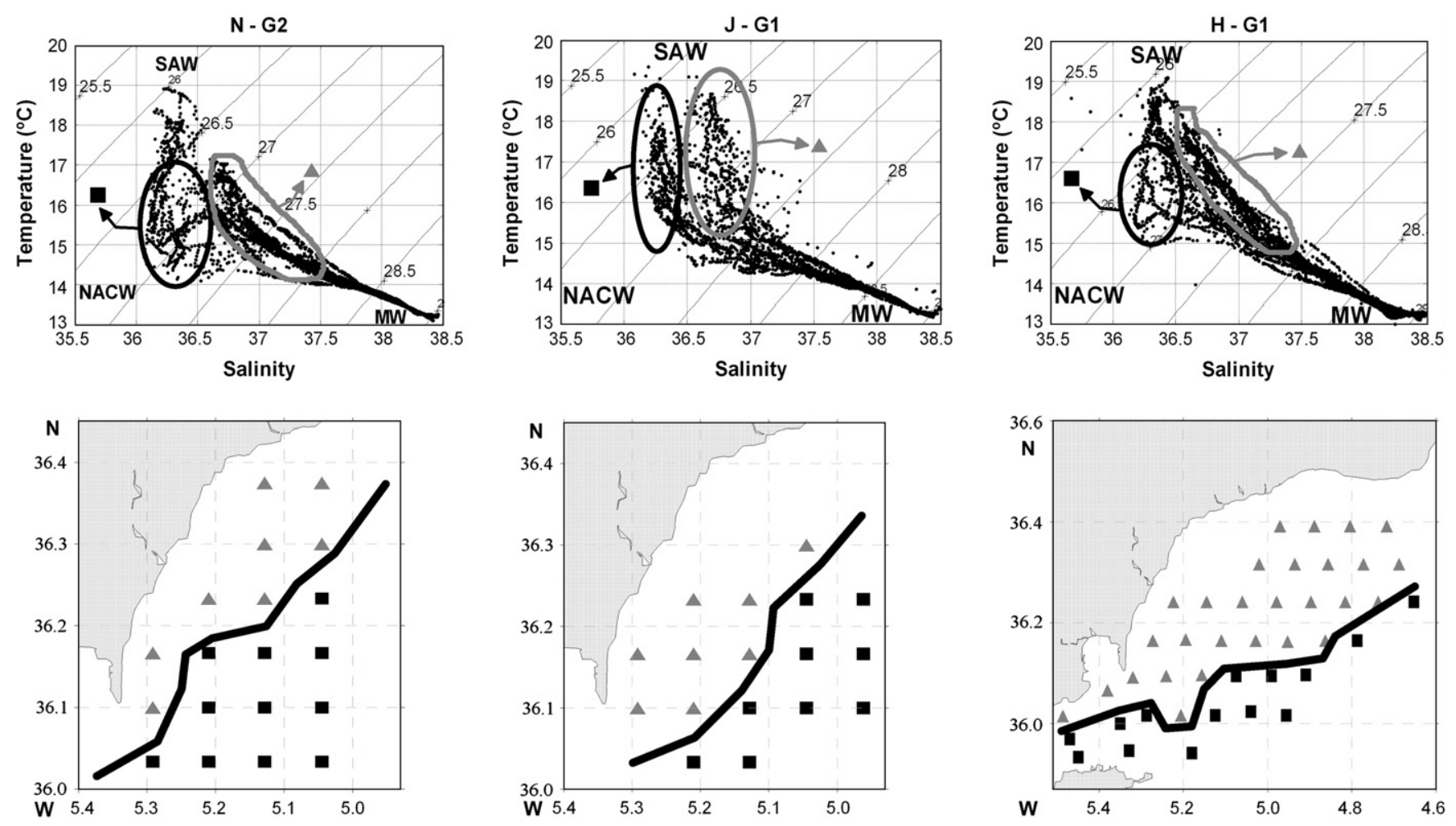

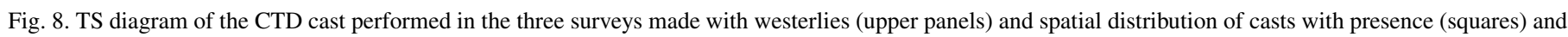

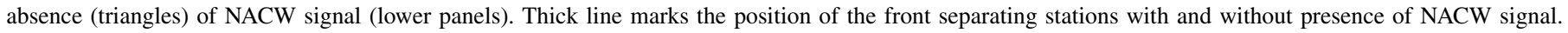

presence of higher proportion of recently-upwelled deep MW. In this same area, a small cyclonic gyre adjacent to the Spanish coast was detected. A clear front between both water masses (defined as the 37 isohaline) was visible in the salinity and temperature maps (thick line in Fig. 9a and b).

Mean surface $(0-50 \mathrm{~m})$ inorganic nutrient concentration distributions (Fig. 9c) showed the highest levels in the north of the sampling grids; associated with the coastal upwelling of MW. Meanwhile, the area occupied by the Atlantic jet typically had lower concentrations of nutrients. These latitudinal differences were especially conspicuous in $\mathrm{H}-\mathrm{G} 1$, the most extensive grid carried out. There was a significant $(p<0.05)$ and negative correlation between surface mean nutrients concentration and temperature (Table 2 and Fig. 10a).

Surface chlorophyll distributions were similar in the three surveys (Fig. 9d), with the maximum values near the Spanish shore and/or associated to the frontal area (linked to the highest concentrations of nutrients) and low levels always found within the Atlantic Jet, in the southern side of the grids. Additionally, a significant correlation (Table 2) between the positions of the deep chlorophyll maximum (DCM) and the nutricline (Znn) was observed (Fig. 10b). There was also a significant correlation between the total chlorophyll concentration and picoplankton cell abundance (Fig. 11a) as well as with chlorophyll in cells $>10 \mu \mathrm{m}$ (Fig. 11b) during H-G1.

\subsection{Easterly winds}

With easterly wind conditions, high atmospheric pressure over the Mediterranean and a weakened inflow could be expected as shown in Section 3.1. Hydrographical structures and variables distribution were clearly different in the surveys carried out under the influence of easterlies (N-G1, J-G2 and H-G2, see Table 1). NACW signal was not detected in the TS diagrams corresponding to the CTD casts carried out in these conditions (Fig. 12). The warm and fresher water found in the south of the sampling grids during westerlies episodes was not present when easterlies prevailed; being also absent the frontal zone (Fig. 13). The Atlantic water was only detected in the southernmost stations located just within the eastern sector of the Strait of Gibraltar during H-G2.

Averaged ADCP velocities within the upper $50 \mathrm{~m}$ measured during H-G2 showed a drastic change in the structure of currents within the NW Alborán Sea (arrows in Fig. 13, right side) during easterlies. Specifically, an extensive cyclonic gyre was found occupying the whole sampled area, with zones in which current lines ran clearly from coast to open sea.

There were also differences in the mean distribution of inorganic nutrients during these surveys, which were probably linked to the mentioned changes in the currents pattern (Fig. 13c). During N-G1 the maximum surface concentration of nutrients was in the open sea area. Whilst during J-G2 and H-G2 high concentrations were observed near the coast, although a displacement of the maximum to the west was observed. In contrast to when westerly winds dominated, no significant correlation was observed between surface nutrient concentrations and temperature (Table 2 and Fig. 10c).

Surface chlorophyll distributions presented a distinctive pattern when easterlies prevailed (Fig. 13d). During N-G1 patches of high chlorophyll concentration were found offshore, 
a
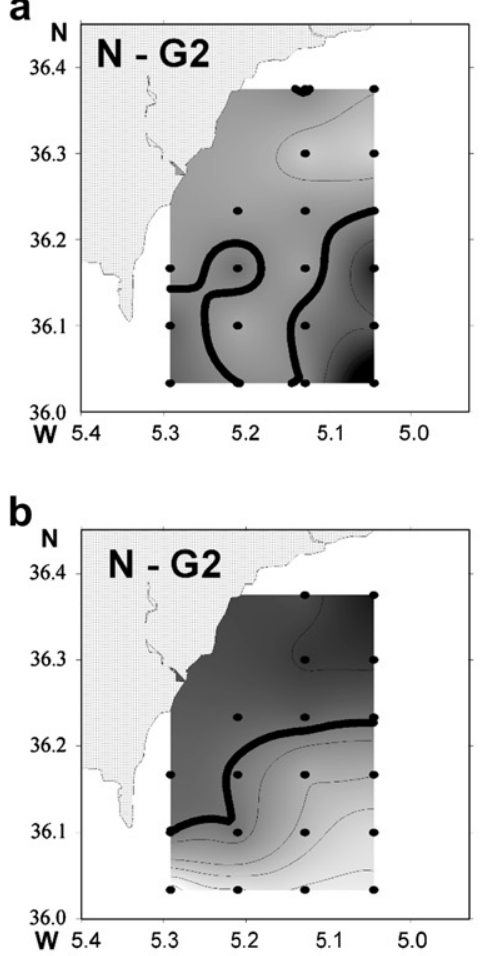

C

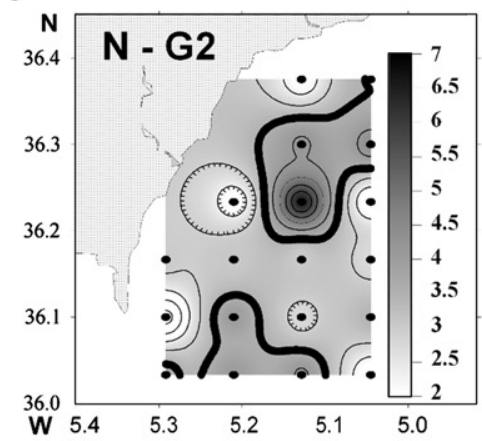

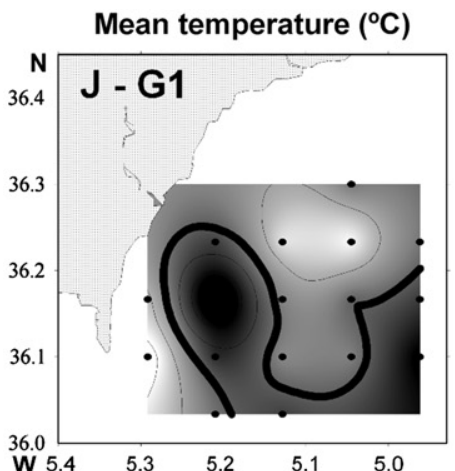

Mean salinity

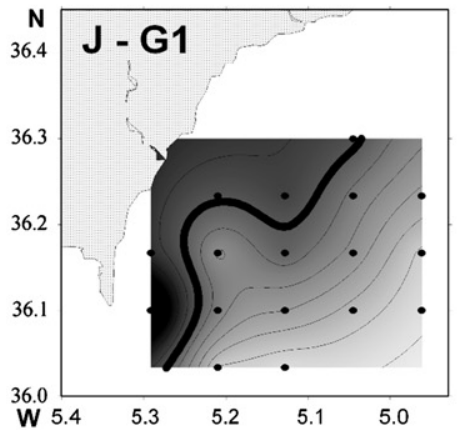

Mean nitrate+nitrite concentration $(\mu \mathrm{m})$

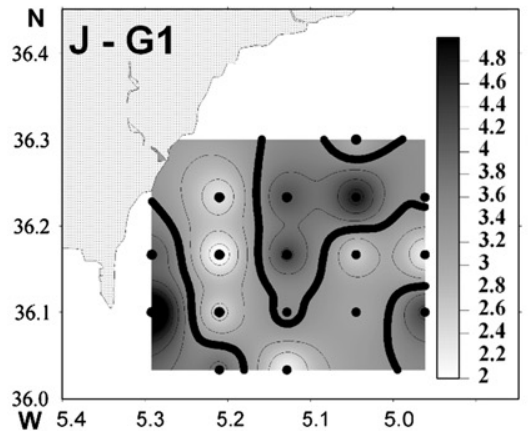

Mean chlorophyll concentration ( $\mathrm{mg} / \mathrm{m} 3)$

d

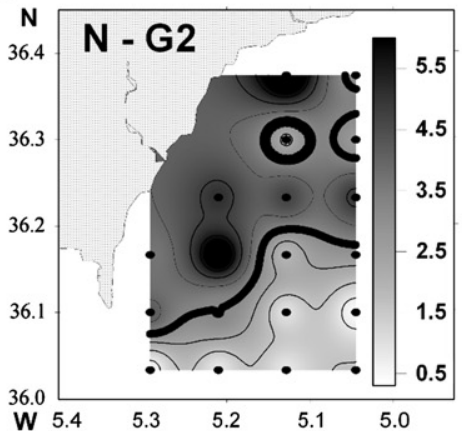

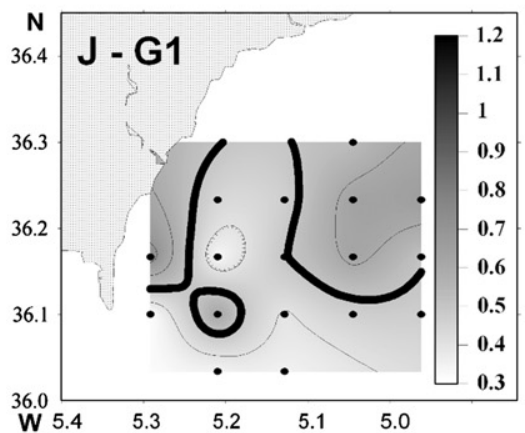


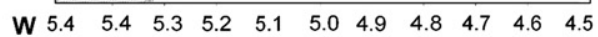

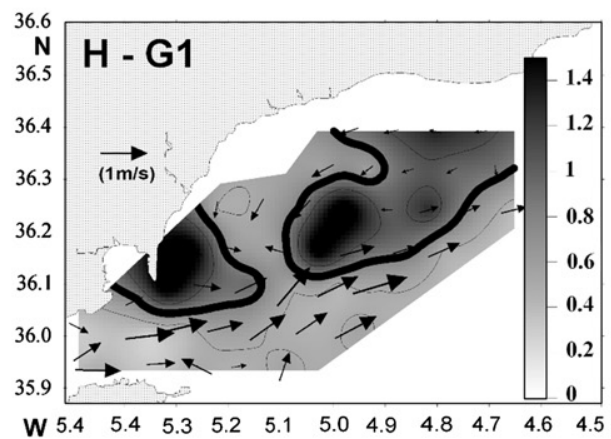

Fig. 9. (a) Mean surface temperature, (b) mean surface salinity, (c) mean surface nutrients and (d) mean surface chlorophyll of the surveys carried out during westerlies. The thick line marks the position of the frontal area separating both water masses ( $\mathrm{a}$ and $\mathrm{b}$ ) and high and low concentration areas of the considered variable (c and d).

far from the coastline, mainly in the north of the sampling area. During J-G2 high chlorophyll concentration patches were present both in the coast and open sea, with a more homogenous distribution. Whilst during the $\mathrm{H}-\mathrm{G} 2$ cruise, the maximum concentrations appeared in the centre of the cyclonic circulation detected with the ADCP data. The correlation between DCM and Znn during easterlies was not significant (Fig. 10d). 
Table 2

Pearson's correlation between surface nutrient concentrations and temperature, as well as between the depth of the deep Chlorophyll maximum, and the nutricline in each survey. $* * * p<0.01, * * p<0.05, * p>0.05$

\begin{tabular}{|c|c|c|c|c|}
\hline \multirow[t]{2}{*}{ Cruise } & \multicolumn{2}{|l|}{ Westerlies } & \multicolumn{2}{|l|}{ Easterlies } \\
\hline & Nuts. vs. Temp & DCM vs. Znn & Nuts. vs. Temp & DCM vs. Znn \\
\hline $\begin{array}{c}\text { November } \\
2002\end{array}$ & $r=-0.42 * *$ & $\boldsymbol{r}=\mathbf{0 . 5 2} * *$ & $\boldsymbol{r}=-\mathbf{0 . 5 8} * *$ & $r=0.4^{*}$ \\
\hline June 2003 & $\boldsymbol{r}=-\mathbf{0 . 7 7} * * *$ & $r=0.63^{*}$ & $r=-0.31^{*}$ & $r=0.32 *$ \\
\hline $\begin{array}{c}\text { Hespérides } \\
2003\end{array}$ & $\boldsymbol{r}=-\mathbf{0 . 7 5} * * *$ & $\boldsymbol{r}=\mathbf{0 . 6 2} * * *$ & $r=-0.32 *$ & $r=0.01 *$ \\
\hline
\end{tabular}

Finally, the chlorophyll maxima detected during these easterly winds conditions were mainly due to big cells (Fig. 11b) as there was no correlation between chlorophyll concentration and picophytoplankton abundance (Fig. 11a).

\section{Discussion}

The results demonstrate the high spatio-temporal variability of the hydrographic structures found within the NW Alboran Sea. Due to the sampling structure used in the present work (2- to 3-day surveys), only subinertial (temporary speaking) variability of such structures could be addressed.

Chlorophyll concentration values in this study matched those previously found using satellite imagery over annual cycles within the area (García-Gorriz and Carr, 1999; Baldacci et al., 2001; Macías et al., 2007). We also found higher values in winter (around $5.5 \mathrm{mg} \mathrm{m}^{-3}$ ) while in summer the maximum was only $2 \mathrm{mg} \mathrm{m}^{-3}$. However, the patterns presented bellow will not be influenced by this long-term cycle as the spatial distribution of a variable should be independent of its absolute value.

\subsection{Westerlies pattern (or enhanced Atlantic inflow)}

Fig. 14a shows the schematic situation in the NW Alborán Sea when westerly winds prevail. The Atlantic jet (black arrow) enters in the vicinity of the Spanish shore (demonstrated by the temperature and salinity distribution in Fig. 9) creating a clear frontal zone between Atlantic and coastal waters (which are more enriched in MW). This jet has a north-eastern direction and a high velocity of around $1 \mathrm{~m} \mathrm{~s}^{-1}$ (as previously reported by Watson and Robinson, 1991). Meandering of the Atlantic jet was clearly visible in the ADCP current data as an alternation of cyclonic and anticyclonic cells (Fig. 9). Further north, a small cyclonic gyre extends from Gibraltar to Malaga Bay close to the Spanish coast.

During westerlies, atmospheric pressure over the Mediterranean Sea is usually lower than average (Fig. 2) and has the direct effect of increasing the inflow of Atlantic waters through the Strait of Gibraltar resulting in a change in the size of the WAG.

For example, during cruise N-G2, when a new WAG seems to be in formation (SST image of Fig. 5d) the atmospheric pressure recorded in the Alboran Buoy was considerably low. Similarly, the SST image acquired a day before the beginning of J-G1 mesh (Fig. 6b) shows a well developed western

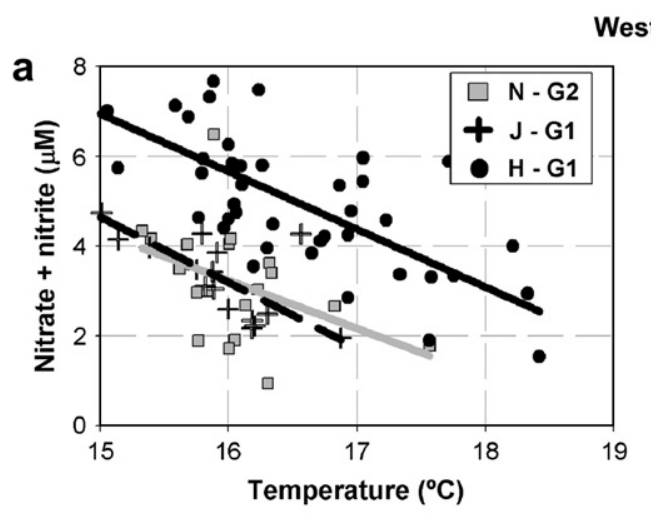

Westerly winds

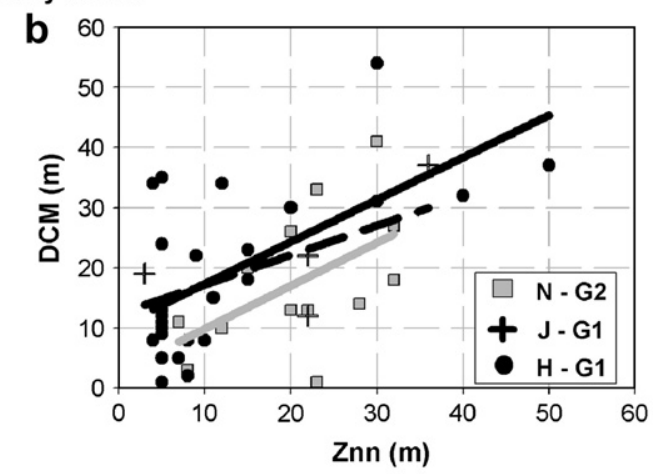

Easterly winds
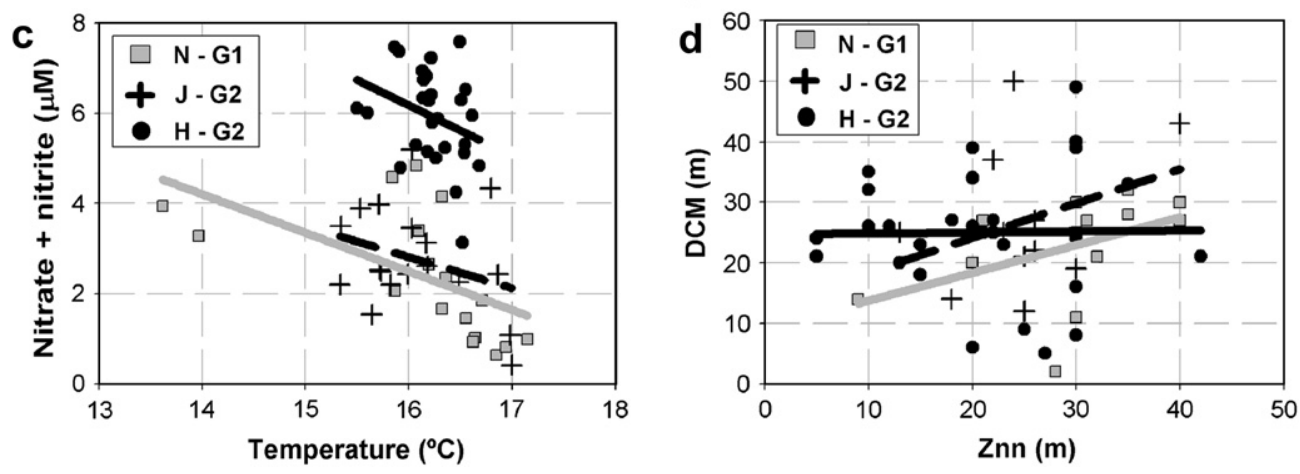

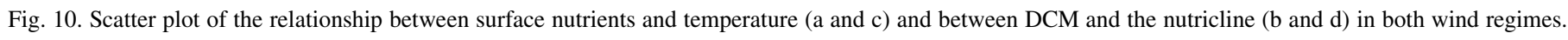


a
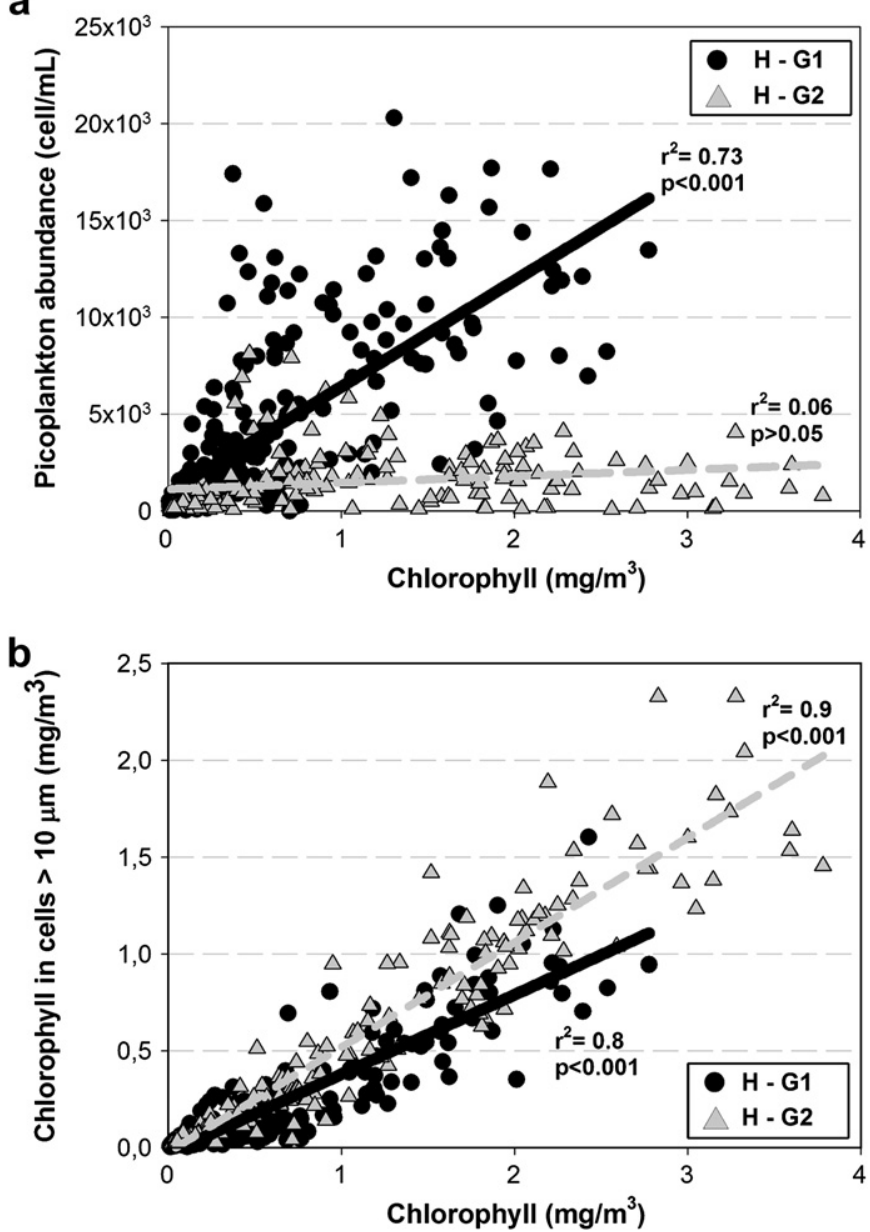

Fig. 11. (a) Relationship between picoplankton abundance and chlorophyll concentration in H-G1 and H-G2. (b) Relationship between chlorophyll in cells larger than $10 \mu \mathrm{m}$ and total chlorophyll concentration in H-G1 and H-G2.

gyre which occupies almost the entire western Alboran Sea. We speculate that inflow intensity must have increased during these two samplings periods since this gyre formation process demands a high intensity of the Atlantic jet, otherwise the jet would flow closer to the African coast as a coastal mode jet (Bormans and Garret, 1989). During H-G1 the situation was also quite similar to the previous description, with lower atmospheric pressure over the Alboran Sea and enhanced inflow of Atlantic waters which was well documented by the mooring situated on the Camarinal Sill (Fig. 7c).

Under these circumstances, maximum surface inorganic nutrients concentrations were found in the vicinity of the coast (Fig. 9c and shadow area in Fig. 14a), although during H-G1 these maxima were also associated with the cyclonic meanders of the Atlantic Jet (Fig. 9c), possibly due to a deficient sampling of the coastal zone, as the survey performed during this cruise did not cover this coastal area (Fig. 1). This inorganic nutrient distribution could be the consequence of the activation of the coastal upwelling phenomena under the influence of westerlies as previously reported in several studies (Minas et al., 1987; Sarhan et al., 2000). In these wind conditions, an ascent of cold and rich deep MW occurs, signified by the negative and significant correlation between average surface nutrients concentration and temperature (Table 2 and Fig. 10a).

Maximum surface chlorophyll concentrations were found in the same coastal area, with a distribution quite similar to that of the nutrients (Figs. 9d and 14a). The spatial coincidence of chlorophyll and nutrient maxima and minimum temperature indicates that the primary production was being driven by nutrient inputs to the upper layer from upwelling. The shallower location of DCM and Znn (Table 3) and the correlation between their vertical positions (Fig. 10b) could be interpreted as additional evidence of the bottom-up control of the phytoplankton community.

Surprisingly, average surface chlorophyll concentrations were lower than during easterly winds (Table 3 ). Nevertheless, studies based on satellite imagery analyses over longer time scales indicate that the highest surface chlorophyll concentrations in the region generally in the northern coastal area when westerlies are blowing (Macías et al., 2007). Therefore, the apparent contradiction with the field data collected in this work could be explained by deficient sampling of the northern coastal area during the surveys.

However, satellite imagery also revealed that the patterns associated with westerlies episodes were also present in the absence of zonal wind (Macías et al., 2007). This fact indicates that the activation of the coastal upwelling processes could (1) happen by wind dragging (in presence of westerly winds) or (2) be due to suction of coastal waters created by the presence of the Atlantic Jet in the vicinity of the shore (for which is only needed a high inflow velocity) and the subsequent development of a cyclonic gyre in the coastal area (clearly visible in our ADCP data). Therefore, the wind only acts as a modulator of the intensity of such processes. Thus the scheme shown in Fig. 14a could be considered as the "more usual" pattern of the study area.

\subsection{Easterlies pattern (or reduced Atlantic inflow)}

The situation found when easterlies prevailed showed essentially different hydrographical features (Fig. 14b).The disappearance of NACW signal in the southern half of the grid could be due to a displacement of the Atlantic jet to the south, out of the sampled area or to a lower input of NACW through the Strait of Gibraltar as a consequence of smaller inflow velocities with this zonal wind (e.g. Gómez et al., 2004).

However, mean surface temperature and salinity distributions (Fig. 13a and b) support the first hypothesis as the Atlantic jet is found far south flowing in a south-east direction. This phenomenon has been previously reported by other authors (García-Lafuente et al., 1998; Sarhan et al., 2000; Macías et al., 2007) and has been explained as a consequence of a diminution of the flow velocity of the Atlantic waters (VargasYañez et al., 2002).

The southward drifting of the Atlantic jet enhances the cyclonic circulation pattern in the north of the sampled area (as can be observed in the ADCP data recorded during H-G2, Fig. 13) and induces strong changes in the surface distribution of several variables (Fig. 13). 



Fig. 12. TS diagram of the CTD cast performed in the three surveys made with easterlies (upper panels) and spatial distribution of casts with presence (squares) and absence (triangles) of NACW signal (lower panels).

Contrary to the previous situation, easterly wind conditions correspond with a higher atmospheric pressure over the Mediterranean Sea (see Fig. 2) which could be responsible for a reduced inflow of Atlantic waters through the Strait of Gibraltar, which has consequences for the development of the WAG.

During the N-G1 cruise the atmospheric pressure over the Mediterranean was notably high (Fig. 5a), probably inducing a decrease in the inflow intensity, which could have been responsible for the WAG situation shown in the SST images of Fig. $5 b$ and c. The WAG was firstly squashing toward the African coast on day 7 November 2002 (Fig. 5a) and later, 8 November 2002 the WAG signature seemed to disappear completely (Fig. 5b). On the other hand, the western gyre signature was absent from the SST image acquired a day before J-G2 (Fig. 6c). We speculate that this fact could be related with a diminution in the inflow intensity caused by the high atmospheric pressure conditions over the western Alboran on these dates. Consequently, after the relaxation of the gyre, the Atlantic jet hardly entered into the measurement grid dominion and was no longer detected. Prevailing easterly winds during both cruises were consistent with the warmer water tongue that was spreading from east to west along the Málaga coast, with the older upwelled water confined to the western side (Figs. 5b and $6 c)$.

As mentioned previously, the situation during the November 2003 cruise was quite different to the previous cruises as subinertial flow was in the same condition (increased flow) during both grids, i.e., during both wind conditions (Fig. 7c).
The reason for the different configuration of the western gyre during these two grids may be due to the different situation that prevailed in the western Alboran Sea waters before the subinertial flow was increased. That is, in the days previous to HG1 (westerly winds) the western gyre was apparent (see SST image in Fig. 7d) and the Atlantic jet was displaced towards the north (Fig. 9). On the contrary, in the days before HG2 (easterly winds) an episode of gyre collapse seemed to develop in the western Alboran Sea (Fig. 7e), which was probably associated with the high atmospheric pressure observed in the western Mediterranean during these previous days (Fig. 7b). Under these circumstances, during HG1 the increased inflow led to a larger gyre (Fig. 7d), while during HG2 the gyre was in an early stage of its formation process in a similar way to that shown in Fig. 7e.

During these periods of easterlies pattern, the maximum surface concentration of nutrients and, especially, chlorophyll were found farther off the coast than with westerlies; being located approximately in the centre of the newly-created cyclonic cell (Fig. 13c and d).This displacement of the chlorophyll maxima offshore when easterly winds are blowing has been previously observed using satellite imagery by Macías et al. (2007) and in field data by Reul et al. (2005). The latter authors related the appearance of these chlorophyll patches with a secondary upwelling created in the open sea area due to the southward displacement of the Atlantic Jet, which would force intermediate-depth MW to ascend towards the surface. However, another possibility for the generation of 
a

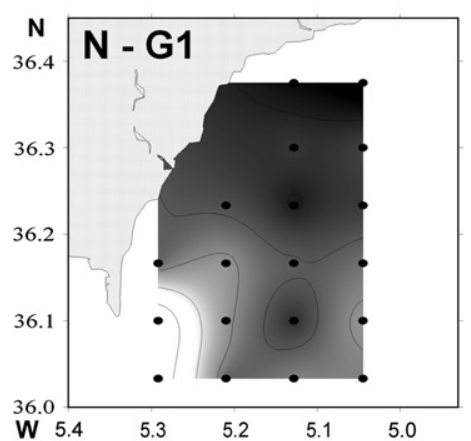

b

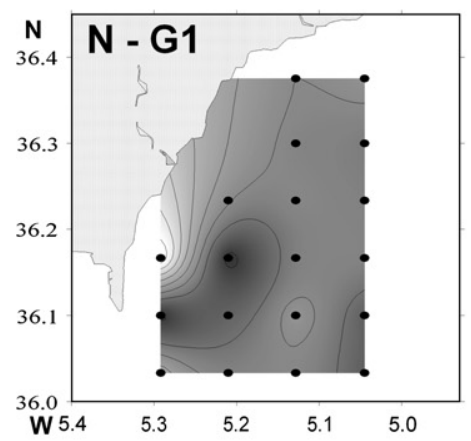

C
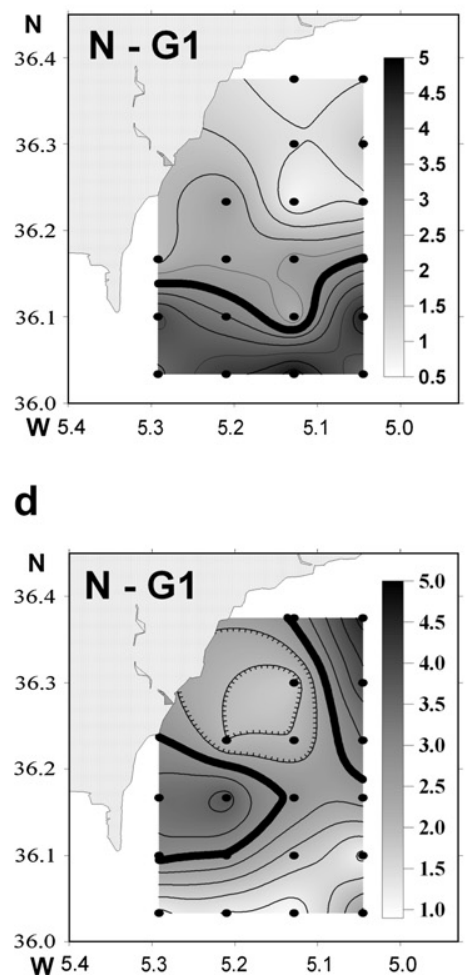

Mean temperature $\left({ }^{\circ} \mathrm{C}\right)$

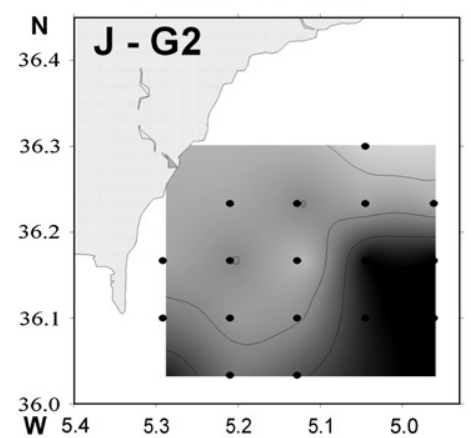

Mean salinity



Mean nitrate+nitrite concentration $(\mu \mathrm{m})$

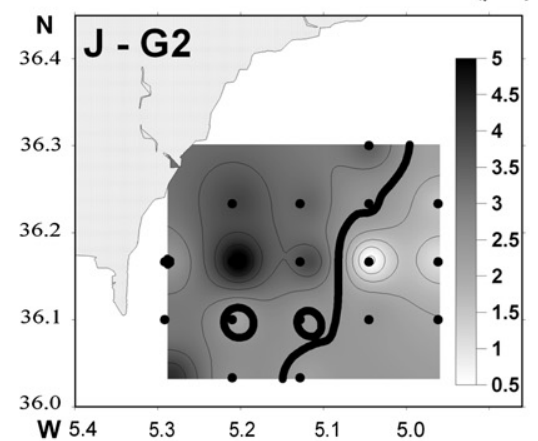

Mean chlorophyll concentration ( $\mathrm{mg} / \mathrm{m} 3)$

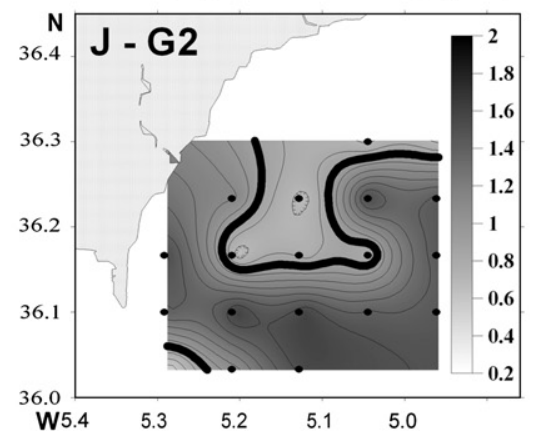

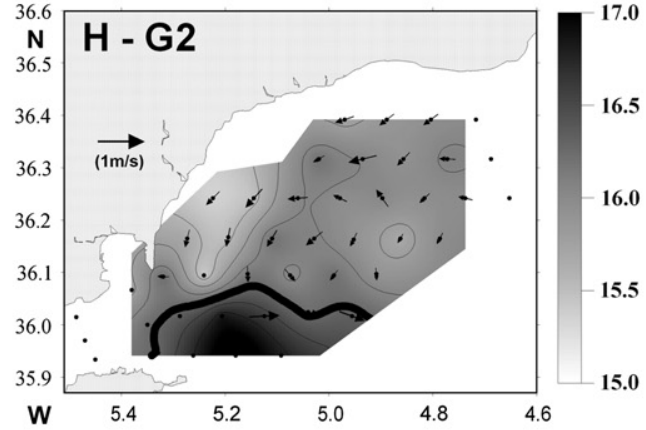
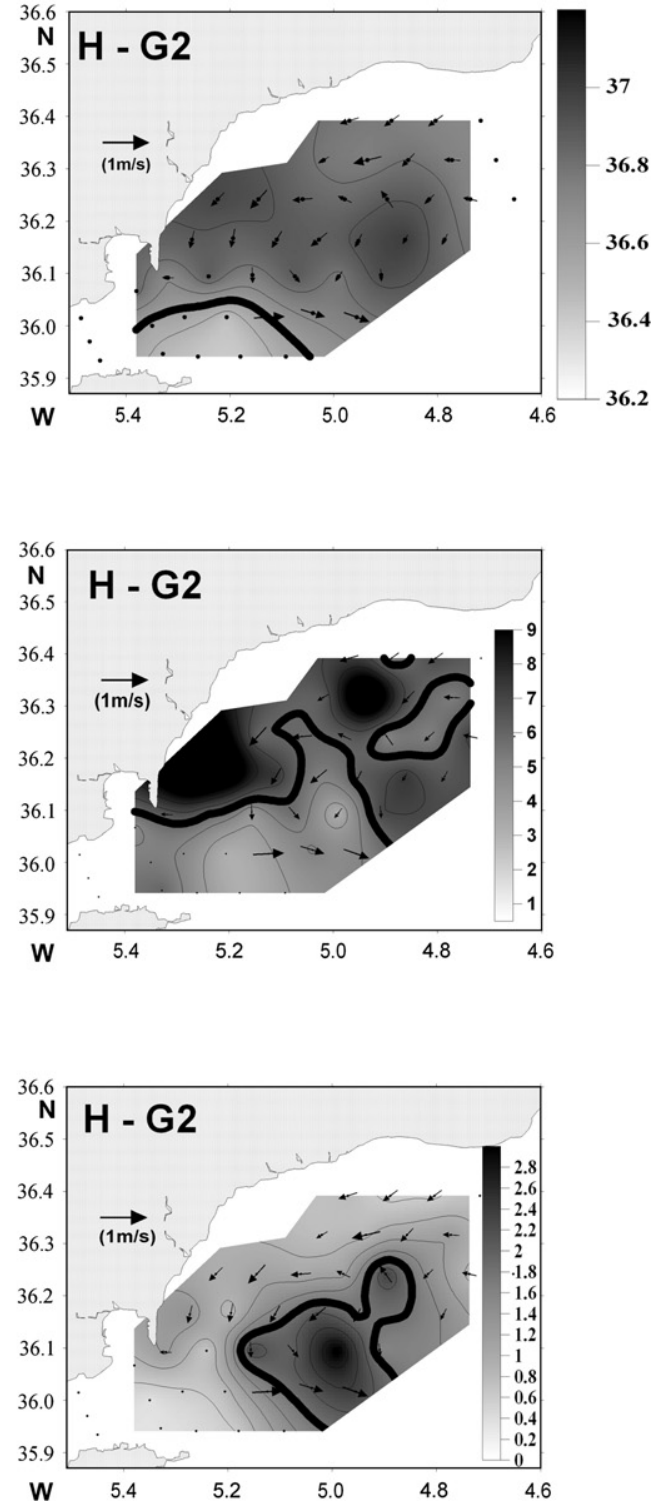

Fig. 13. (a) Mean surface temperature, (b) mean surface salinity, (c) mean surface nutrients and (d) mean surface chlorophyll of the surveys carried out with easterlies. 



Fig. 14. Conceptual schemes of the spatial distribution of the Atlantic Jet (black arrow), maximum surface concentrations of nutrients and chlorophyll (grey area) and secondary circulation patterns (grey arrow). (a) With westerlies; (b) with easterlies.

these patches is the advection of coastal waters to the south due to the change in the currents regime of the area.

Several results of the present work seem to indicate that the second hypothesis presented in the above paragraph is the most suitable to explain our data. First of all, the ADCP data recorded during easterly winds (Fig. 11) clearly shows current lines that run from the coast to the open sea in some areas. The lack of correlation between surface nutrients and temperature (Fig. 10c) could indicate a relaxation of the upwelling processes and a warming of the upwelled waters while they are advected from the coastal area in the surface layer driven by the offshore currents (Fig. 13). The exception is N-G1 where a significant correlation between temperature and nutrients is found (Table 2).

Table 3

Comparison of average surface values of several variables during westerly and easterly conditions. *Differences not significant $\left(t_{0.05(2)}\right)$; **differences significant $\left(t_{0.05(2)}\right)$

\begin{tabular}{lllc}
\hline & $\begin{array}{l}\text { Average value } \\
\text { with westerlies }\end{array}$ & $\begin{array}{l}\text { Average value } \\
\text { with easterlies }\end{array}$ & $\%$ of difference \\
\hline DCM depth $(\mathrm{m})$ & 19 & 25 & $31 *$ \\
Znn depth $(\mathrm{m})$ & 16 & 24 & $\mathbf{4 9 * *}$ \\
Chlorophyll $a\left(\mu \mathrm{g} \mathrm{L}^{-1}\right)$ & 0.69 & 1.23 & $\mathbf{7 7 * *}$ \\
\hline
\end{tabular}

This could be due to the short time period of the easterlies episode during this cruise (Table 1) which only started 1 day before the beginning of the sampling ( 6 November). In this case, even though the mean zonal wind was from the east (Table 1), the short duration of the wind episode prevented the system from reaching a fully developed "easterlies" pattern, leading to an intermediate state between both regimes.

Further evidence of the coastal origin of the chlorophyll patches is the higher average concentration found during easterlies (Table 3). As reported above, the coastal area was undersampled due to the grid design (Fig. 1) and therefore during westerly winds maximum chlorophyll concentrations could not be registered. However, when easterlies blow, this coastal patch is displaced offshore, increasing the observed average surface concentration of the sampling grid (Table 3).

Both DCM and Znn are located deeper with easterlies than with westerlies (Table 3), supporting the hypothesis of relaxation of upwelling phenomena. On the other hand, the non-existence of a relationship between DCM and Znn (Fig. 10d) is an indication that the distribution of phytoplankters is not only controlled by nutrients availability, being necessary to consider other processes such as, for example, physical advection by currents.

The significant correlations between total chlorophyll and size-fractionated chlorophyll (Fig. 11) are additional evidence of the coastal origin of the chlorophyll maxima found during easterlies. With westerly winds there was a significant correlation between total chlorophyll concentration and the abundance of both picoplankton (Fig. 11a) and cells $>10 \mu \mathrm{m}$ (Fig. 11b), indicating that the phytoplankton assemblage in this meteorological situation was well mixed and was not sorted by any physical or biological mechanism. However, when easterlies prevail, the chlorophyll patches seem to be mainly formed by big cells, demonstrated by the lack of correlation between picoplankton and chlorophyll (Fig. 11a), together with the significant correlation between total chlorophyll and chlorophyll in cells $>10 \mu \mathrm{m}$ (Fig. 11b). This size structure of the phytoplankton community is typical of more eutrophic environments, again supporting the hypothesis of a coastal water mass being advected towards the open sea by the surface off-shore currents. However, further work must be carried out to elucidate whether or not there was a real change in the phytoplankton assemblage using, for example, optical microscopy analysis.

Nevertheless, there should be a wide variety of intermediate situations between the two typical stages presented in this work. It is usually accepted that the circulation in this basin is always changing in continuous adjustment process among the different water masses present in the region and the external forcing (Tintoré et al., 1994). Also there should be many other factors apart from the wind field that can introduce additional variability which cannot be eliminated in the interpretation of the observed patterns, such as tidal cycles or several types of variations in the water budgets between Atlantic and Mediterranean basins. More field work, remote sensing observations and modelling studies should be carried out in the near future for a better understanding of the mechanisms working in this highly dynamic area. 


\section{Conclusions}

Mesoscale hydrological structures and biological patterns in NW Alboran Sea are influenced by the atmospheric pressure over the Mediterranean Basin. Atmospheric pressure modulates both the intensity of the Atlantic inflow through the Strait, which in turn affects the formation and extension of the WAG, and the zonal wind field in the region.

It is possible to identify two typical situations. (1) When zonal winds are predominantly from the west (corresponding with low atmospheric pressure in the Mediterranean and enhanced inflow) the Atlantic jet flows near the Spanish coast, coastal upwelling is activated, and a phytoplankton distribution is mainly controlled by nutrient availability. (2) When easterly winds blow (corresponding with higher atmospheric pressure over the Mediterranean and lower inflow of Atlantic waters), the Atlantic jet is displaced offshore to the south of the basin, an enhanced cyclonic circulation appears in the shelf area, and additional forcing factors (e.g., advection) influence the distribution of the phytoplankton community.

\section{Acknowledgements}

This work was supported by the Spanish National Research Plan; projects CICYT REN-2001-2733-C02-02/1 and CTM2005-08142-C03-01/2002. D.M. and A.V. were supported by grants from the FPI fellowship program. We would like to thank Gabriel Navarro for his support in the treatment of SST images and Dr. E.P. Morris for his kind revision of the text.

\section{References}

Arnone, R.A., Wiesenburg, D.A., Saunders, K.D., 1990. The Origin and Characteristics of the Algerian Current. Journal of Geophysical Research 95 (C2), 1587-1598.

Baldacci, A., Corsini, G., Grasso, R., Manzella, G., Allen, J.T., Cipollini, P., Guymer, T.H., Sanith, H.M., 2001. A study of the Alboran sea mesoscale system by means of empirical orthogonal function decomposition of satellite data. Journal of Marine Systems 29, 293-311.

Benzohra, M., Millot, C., 1995. Characteristics and circulation of the surface and intermediate water masses off Algeria. Deep-Sea Research I 42 (10), $1803-1830$

Bormans, M., Garret, C., 1989. A simple criterion for gyre formation by the surface outflow from a strait, with application to the Alboran Sea. Journal of Geophysical Research 94 (C9), 12637-12644.

Bray, N.A., Ochoa, J., Kinder, T.H., 1995. The role of interface in exchange through the Strait of Gibraltar. Journal of Geophysical Research 100 (C6), 10755-10776.

Candela, J., Winant, C., Bryden, H., 1989. Meteorologically forced subinertial flows through the Strait of Gibraltar. Journal of Geophysical Research 94 (C9), 12667-12679.

Cheney, R.E., Doblar, R.A., 1982. Structure and variability of the Alborán Sea frontal system. Journal of Geophysical Research 87 (C1), 585-594.

Crepon, M., 1965. Influence de la pression atmospherique sur le niveau moyen de la Mediterranee Occidentale et sur le flux a travers le detroit de Gibraltar. Cahiers Oceanographiques 1 (7), 15-32.

Eppley, R.W., Rogers, J.N., McCarthy, J.J., 1969. Half saturation contrast for uptake of nitrate and ammonium by marine phytoplankton. Limnology and Oceanography 14, 912-920.
García-Gorriz, E., Carr, M.-E., 1999. The climatological annual cycle of satellite-derived phytoplankton pigments in the Alboran Sea. Geophysical Research Letters 26 (19), 2985-2988.

García-Lafuente, J., Cano, N., 1994. Tidal dynamics and associated features of the northwestern shelf of the Alboran Sea. Continental Shelf Research 14 (1), 1-21.

García-Lafuente, J., Cano, N., Vargas, M., Rubín, J.P., Hernandez-Guerra, A., 1998. Evolution of the Alboran Sea hydrographic structures during July 1993. Deep Sea Research I 45, 39-65.

García-Lafuente, J., Sarhan, T., Vargas, M., Vargas, J.M., Plaza, F., 1999. Tidal motions and tidally induced fluxes through La Línea submarine canyon, western Alboran Sea. Journal of Geophysical Research 104 (C2), 3109-3119.

García-Lafuente, J., Delgado, J., Vargas, J.M., Vargas, M., Plaza, F., Sarhan, T., 2002. Low frequency variability of the exchanged flows through the Strait of Gibraltar during CANIGO. Deep-Sea Research II 49 (19), 4051-4067.

Gil, J., 1994. Circulación Geostrófica e Hidrografía del Mar de Alborán en la Campaña IctioAlborán 0792. Informe técnico Instituto Español de Oceanografía 146, 9-26.

Gleizon, P., Chabert d'Hieres, G., Renouard, D., 1996. Experimental study of the Alboran Sea gyres. Oceanologica Acta 19 (5), 499-511.

Gómez, F., Gorsky, G., García-Górriz, E., Picheral, M., 2004. Control of the phytoplankton distribution in the Strait of Gibraltar by wind and fortnightly tides. Estuarine, Coastal and Shelf Science 59, 485-497.

Gomís, D., Pedder, M.A., Viúdez, A., 1997. Recovering spatial features in the ocean: performance of isopycnal vs. isobaric analysis. Journal of Marine Systems 13, 205-224.

Holm-Hassen, O., Lorenzen, C.J., Homes, R.W., Strickland, J.D.H., 1965. Fluorometric determination of chlorophyll. Journal Conseil Permanent International l'Exploration de la Mer 187, 9-18.

La Violette, P.E., 1984. The advection of submesoscale thermal features in the Alboran Sea gyre. Journal of Physical Oceanography 14, 550-565.

Lacombe, H., 1971. Le Dètroit de Gibraltar; Oceanographique Physique. In: Mèmorie explicatif de la carte gèotechnique de Tanger au 1/250000, 222, pp. 111-146. Notes et Mém. Serv. Gèologique. Maroc.

Lanoix, F., 1974. Etude hydrologique et dynamique de la mer d'Alboran. North Atlantic Treaty 66, 32.

Macías, D., 2006. Efectos biológicos de la mezcla interfacial y de los procesos hidrodinámicos mesoescalares en el Estrecho de Gibraltar. PhD Thesis, University of Cadiz, Spain.

Macías, D., García, C.M., Echevarría, F., Vázquez-Escobar, A., Bruno, M., 2006. Tidal induced variability of mixing processes on Camarinal Sill (Strait of Gibraltar). A pulsating event. Journal of Marine Systems 60, 177-192.

Macías, D., Navarro, G., Echevarría, F., García, C.M., Cueto, J.L., 2007. Phytoplankton distribution in the north-western Alboran Sea and meteorological forcing: a remote sensing study. Journal of Marine Research 64 (4), 523-543.

Minas, H.J., Coste, B., Minas, M., 1987. Le Detroit de Gibraltar et ses aires peripheriques: un site de forte productivite permanente. IFREMER 2e Coll. Franco-Soviétique, Yalta, 41-42.

Packard, T.T., Minas, H.J., Coste, B., Martinez, R., Bonin, M.C., Gostan, J., Garfield, P., Christensen, J., Dortch, Q., Minas, M., Copin-Montegut, G., Copin-Montegut, C., 1988. Formation of the Alboran oxygen minimum zone. Deep-Sea Research 35 (7), 1111-1118.

Perkins, H., Saunders, K.D., 1984. Sections of current, salinity and temperature in the northwestern Alboran Sea, October 1982. In: Parrilla, G. (Ed.), Donde Va? Meeting report, October 1983. Instituto Español de Oceanografía, Fuengirola.

Perkins, H., Kinder, T.H., La Violette, P.E., 1990. The Atlantic inflow in the western Alboran Sea. Journal of Physical Oceanography 20, 242263.

Prieto, L., García, C.M., Corzo, A., Ruíz, J., Echevarría, F., 1999. Phytoplankton, bacterioplankton and nitrate reductase activity distribution in relation to physical structure in the southern Alborán Sea and Gulf of Cádiz (southern Iberian Peninsula). Boletin del Instituto Español de Oceanografía 14 (1-4), 401-411. 
Reul, A., Rodríguez, V., Jiménez-Gómez, F., Blanco, J.M., Bautista, B., Sarhan, T., Guerrero, F., Ruíz, J., García-Lafuente, J., 2005. Variability in the spatio-temporal distribution and size-structure of phytoplankton across an upwelling area in the NW-Alboran Sea, (W-Mediterranean). Continental Shelf Research 25, 589-608.

Rodríguez, J., Blanco, J.M., Jiménez-Gómez, F., Echevarría, F., Gil, J., Rodríguez, V., Ruiz, J., Bautista, B., Guerrero, F., 1998. Patterns in the size structure of the phytoplankton community in the deep fluorescence maximum of the Alboran Sea (southwestern Mediterranean). Deep-Sea Research I 45, 1577-1593.

Rubín, J.P., Gl, J., Ruíz, J., Cortés, M.D., Jiménez-Gómez, F., Parada, M., Rodríguez, J., 1992. La distribución ictioplanctónica y su relación con los parámetros físicos, químicos y biológicos en el sector norte del mar de Alborán, en Julio de 1991 (resultados de la campaña Ictioalborán 0791). Informe técnico Instituto Español de Oceanografía. 139.

Sarhan, T., García-Lafuente, J., Vargas, M., Vargas, J.M., Plaza, F., 2000. Upwelling mechanisms in the northwestern Alboran Sea. Journal of Marine Systems 23, 317-331.

Strickland, J.D.H., Parsons, T.R., 1972. A Practical Handbook of Seawater Analysis. Bulletin 167, second ed. Fisheries Research Board of Canada. $1-310$.
Tintoré, J., Gomís, D., Alonso, S., Parrilla, G., 1991. Mesoscale dynamics and vertical motion in the Alboran Sea. Journal of Physical Oceanography 21, 20-83.

Tintoré, J., Viúdez, A., Gomís, D., Alonso, S., Werner, F., 1994. Mesoscale variability and $\mathrm{Q}$ vector vertical motion in the Alboran Sea. In: La Violette, P.E. (Ed.), Seasonal and Interannual Variability of the Western Mediterranean Sea. American Geophysical Union, 373 pp.

Vargas-Yañez, M., Plaza, F., García-Lafuente, J., Sarhan, T., Vargas, J.M., Vélez-Belchi, P., 2002. About the seasonal variability of the Alboran Sea circulation. Journal of Marine Systems 35, 229-248.

Viúdez, A., Haney, R.L., Tintoré, J., 1996. Circulation in the Alborán Sea as determined by quasi-synoptic hydrographic observations. Part II: Mesoscale ageostrophic motion diagnosed through density dynamical assimilation. Journal of Physical Oceanography 26, 706-724.

Wash, J.J., 1988. On the Nature of Continental Shelves. Academic Press, New York. 126.

Watson, G., Robinson, I.S., 1991. A numerical model of internal wave refraction in the Strait of Gibraltar. Journal of Physical Oceanography 21, 185-204.

Yentsch, C.S., Menzel, D.W., 1963. A method for the determination of phytoplankton chlorophyll and phaeophytin by fluorescence. Deep-Sea Research 21, 1191-1218. 